\section{Science News a Century Ago}

\section{Giraffes for the Zoological Society}

AT a meeting of the Zoological Society held on February 9, 1836, a letter was read which had been received from M. Thibaut at Malta, giving an account of the capture and condition of four giraffes which he had procured for the Society. He started from Cairo on April 15, 1834, and arrived at.Dongola on July 14, 1834, whence he proceeded by caravan to the deserts of Cordova. On August 16 the Arab hunters succeeded in tracking a full-grown female accompanied by a young one. They soon overtook the former on their fleet coursers, and killed it. The next day they captured the young one. It was necessary to keep it some distance from the caravan for three or four days in order progressively to accustom it to society, when it began to take food, principally of camels' milk. M. Thibaut remained three months in the desert and captured four other giraffes. Difficulty was experienced in transporting them to Cairo and to Malta, but since they had arrived at the latter place every attention was being paid them by Mr. Boucher, the Consul-General. (Athenreum.)

\section{Commodore Barron's Steam Ram}

Thougr Captain John Ross in his "Treatise on Navigation by Steam", 1828, had pointed out that a steam man-of-war could disable an opponent by ramming her, the first description of a steam ram was probably that given by Commodore James Barron, U.S.N., on February 11, 1836. His proposed vessel, which he called a "prow-ship", was to have a triple hull. The middle vessel was to be $150 \mathrm{ft}$. long, $20 \mathrm{ft}$. wide, and the side vessels $125 \mathrm{ft}$. long and $20 \mathrm{ft}$. wide. The prow of the middle hull was to be of solid timbers with iron plates 3 or 4 inches thick affixed to them. The vessel was to be driven by paddle wheels placed between the hulls, the power being supplied by three 120-horse power engines; the speed of the vessel was to be about 8 or 10 knots. "The object of this vessel," said the inventor, "is to destroy men-of-war by running into them with such impetuosity as to break down their sides sufficiently to admit water in such quantities as would defy all possible efforts to prevent immediate sinking. ... Ancient as well as modern history furnished us with many proofs of the decided effects of this mode of attack. . . . The instances of destruction occasioned to vessels by one running into another are too numerous to admit of a doubt that if the plan recommended above should be adopted on a proper scale, it could never fail of effecting its object." According to Admiral G. N. Preble, U.S.N., a model of the prow-ship was exhibited in 1836 in the rotunda of the Capitol at Washington, and was afterwards removed for preservation to the Naval Academy, Annapolis.

\section{Description of the Daniell's Cell}

ON February 11 and 18, 1836, a paper was read before the Royal Society entitled "On Voltaic Combination", the paper being in the form of a letter addressed to Faraday by J. F. Daniell, professor of chemistry in King's College, London. The author, after expressing his obligations to Faraday for the important light which his research in electricity had thrown on chemical science, proceeded to state that he had obtained further confirmation of that great principle discussed and established by Faraday, namely, the definite chemical action of electricity, and had thus been led to the construction of a voltaic arrangement which furnished a constant current of electricity for any required length of time. After describing various experiments, Daniell said that his constant battery consisted of a hollow copper cylinder, containing within it a membranous tube formed by the gullet of an ox, in the axis of which is placed a cylindrical rod of zinc. The dilute acid was poured into the membranous tube, and the space between the tube and the cylinder was filled with a solution of sulphate of copper. When the battery was charged in the manner he described, it produced a perfectly equal and steady current of electricity for many hours together.

\section{Anatomy, Physiology and Pathology of the Brain}

"A Course of Lectures on these interesting and important subjects was commenced by Dr. Spurzheim on Thursday last, in the Webb St. Theatre of Anatomy, in the presence of a very numerous class of Medical Students. The Doctor, in an admirable Introductory Address, forcibly illustrated the advantages which must result to medical practitioners from their being acquainted with the structure of the brain, and with its healthy and diseased functions, and commented in a spirited manner on the insane practice which an ignorance of these subjects leads people to adopt, with a view to curo insanity.

"The lecture was exceedingly well received, and appeared to give great satisfaction. We have no doubt that all classes of medical men will feel it a duty to attend these valuable Discourses." (Lancet, February 11, 1836.)

\section{Societies and Academies}

\section{LONDON}

Royal Society, January 30. R. A. McCANCE : Experimental sodium chloride deficiency in man. Three subjects were subjected to a weighed diet containing minimal quantities of sodium ehloride. Fluids were not restricted. The protein intake was augmented by incorporating 'ashless' casein in the diet. Sweat. ing was carried out in a radiant heat bath, and the sweat was collected quantitatively on mackintosh sheeting. Urine, fæces and insensible perspiration were also collected. The sodium, chloride, nitrogen and potassium balances were determined on two subjects. The deficiency, which was severe, led to a loss of 25-35 per cent of the body sodium. The symptoms were loss of the sense of flavour, con. siderable weakness and fatigue, a sense of constriction in the chest on the least exertion, and cramps. The subjects at first lost weight pari passu with sodium, but later the weight ceased to fall and thereates fluctuated without reference to the sodium. Many of the symptoms and signs and also the blood changes closely reproduced clinical or experimental Addison's disease, but there were points of difference also, for example, no fall of blood pressure. As sodium chloride was restored, the weight rose, the nitrogen balance became positive, the blood urea fell, and 